\title{
SOCIALIZATION OF MOBILE BANKING AND INTERNET BANKING FOR MIKRO AND SMALL ENTREPRENEUR (GENDER AND BUSINESS SECTOR PERSPECTIVE- KEMAYORAN NIGHT MARKET COMMUNITY)
}

\author{
Lucky Nugroho, Nurul Hidayah, Ahmad Badawi, and Anees Janee Ali \\ Universitas Mercu Buana Jakarta, Indonesia \\ Universiti Sains Malaysia, Malaysia.
}

\begin{abstract}
Abstract: The aim of this socialization is to increase the usage of mobile banking and internet banking applications by micro and small entrepreneurs in the Kemayoran Night Market community. The method used through socialization is related to the benefits and ways of utilizing mobile and internet banking to micro and small entrepreneurs. Grounded along with the outcomes of the study at the time of the activity, it was found that female entrepreneurs had a profound understanding of the use of mobile and net banking facilities compared to male entrepreneurs. In summation, it is also known that the business sector in the field of Bags, Shoes \& Clothing, and food \& beverages uses the most mobile and net banking facilities. Therefore socialization is needed related to understanding the functions and benefits of mobile banking and internet banking to micro and small female entrepreneurs.
\end{abstract}

Keywords: Mobile Banking, Internet Banking, Micro \& Small Entrepreneur, Gender, Business Sector

\section{INTRODUCTION}

Technological developments in the financial sector have become a necessity that affects micro and small entrepreneurs must be able to adjust business transactions following the wishes of the community. As is known at this time internet user in Indonesia out of a total population of 264 million people in Indonesia, there are 171.17 million people or around 64.8 percent who have been connected to the internet (Yudha Pratomo, 2019). Based on this, micro and small entrepreneurs must be able to use the mobile and internet banking facilities that are commonly provided by banks. The benefits of mobile banking and internet banking for micro and small entrepreneurs are to increase their sales turnover and also to reduce the risk of losing their money. Mobile banking is a service provided by banks to conduct various banking transactions through sharing features available on smartphones. This mobile banking service is almost the same as the SMS banking service, but mobile banking has more features compared to SMS banking. While internet banking is a transaction activity related to banking, transaction activities can be done in the office, home, or other places using the internet network.

The majority of people in urban areas are now using smartphones as mandatory devices in their activities, especially in millennials generation (Adiarsi et al., 2015; Ainiyah et al., 2018; Mulyana et al., 2018). Fact according to Endy Purwanto (2019), Smartphone users in Indonesia in 2018 have reached 103 million people, and Indonesia is a country ranked $24^{\text {th }}$ in the world as a country whose majority of people have used smartphones. As we know, a smartphone is a handheld phone that has features or high-level capabilities so that its use resembles a computer. Furthermore, Indonesia's economy is currently dominated by the middle class, estimated at 2019, has reached 60 million people (KEMENKEU, 2019; Rizky Alika, 2019). Therefore, the middle class has a significant role in increasing economic growth, due to the consumption of the middle class so that there is demand for goods or services that drive the real sector (Jati, 2015; Pressman, 2015; Sridharan, 2004).

The dynamics of technological development as a value-added business will contrast with the characteristics of micro and small entrepreneurs who have limitations on the use of information technology due to their low education (Linawati \& Restuti, 2015; Nugroho \& Chowdhury, 2015). Besides, the characteristics of micro and small entrepreneurs that cause their strong resilience to the economic crisis include high business turnover; not sensitive to interest rates; and has honesty and discipline in running his business (Jaidan, 2010; Kristiyanti, 2012). Also, efforts to improve the welfare of micro and small entrepreneurs are part of Sustainable Development Goals (SDG's) activities that are included in the action of no poverty. Besides that, micro and small female entrepreneurs are also the focus of SDG's action. In previous studies, it was found that the knowledge of micro and small female entrepreneurs in developing countries (Indonesia and Bangladesh) was lower compared to male entrepreneurs (Nugroho \& Chowdhury, 2015). Therefore the ability of micro and small entrepreneurs, especially women entrepreneurs needs to be improved. 
Furthermore, this study aims to find out how many women entrepreneurs have used mobile and internet banking at Kemayoran Night Market Community and what business sectors use mobile and internet banking a lot. This research contributes to providers of mobile and internet banking in determining their target markets and the benefits for decision making to improve the ability of micro and small entrepreneurs (MSEs) to use information technology mobile banking and internet banking which aim to increase their sales turnover. The limitations of this study are based on research questions that include:

- How many micro and small women entrepreneurs use mobile and internet banking to support their business?

- What business sectors of micro and small entrepreneurs use the most mobile applications and internet banking in their transactions?

\section{LITERATURE REVIEW}

Micro and small women entrepreneurs have a crucial role in the family in improving the welfare of the family. Nevertheless, according to Nugroho \& Chowdhury (2015) and Prastowo (2015) from a psychological perspective, their children will emulate the independence of their mothers as entrepreneurs. In other words, women entrepreneurs will produce successful entrepreneurs (their children) who will come. Typically household financial needs are met by the husband, and however, due to poverty, the wife will help the husband to fulfill his family's needs by becoming an entrepreneur. Therefore micro and small women entrepreneurs tend to run their businesses through their homes because they also have an obligation to take care of the household and care for their children.

Regarding Munizu, (1990) and Sumantri et al., (2013) the knowledge of micro and small female entrepreneurs is lower when compared to male entrepreneurs, so the need for women's empowerment. Empowering poor women is considered not only because of human rights issues but also because of its potential to improve welfare. The empowerment of poor women aims to enhance their status, which is very important to realize economic and development potential in a society which will further create sustainable development (Chaudhry \& Nosheen, 2009; Khan \& Maan, 2008; Rahman et al., 1970). Based on some previous research results, it is concluded that economic factors and behavior change are very significant in empowering poor women, while political participation does not significantly contribute to women's empowerment (Sheikh et al., 2016; Tijani \& Yani, 2007; Wallentin, 2008). Also, formal education for poor women has an impact on increasing women's empowerment so that they can work by their abilities and knowledge which then has an, impact on improving the welfare of families and communities (Gholipour et al., 2010; Hidayah et al., 2018; Najjar, 2011). If it is related to the development of information technology in the banking sector related to banking facilities, micro and small women entrepreneurs should use mobile banking and internet banking services in conducting their business. However, there are obstacles to their lack of education and knowledge so that they are more likely to use traditional methods in carrying out their financial transactions. Knowledge means everything that is known is related to information (Nisak et al., 2013). Knowledge is also information about a specific or universal good in the form of methods, processes, patterns, and existing structures (Yazdi, 2012). Knowledge can be influenced by many things, including factors in formal education and informal education. A person's experience of an object contains two aspects, namely, positive and negative aspects. These positive and negative aspects will determine a person's attitude, the more positive aspects, the more positive the prospective customer's attitude towards the object. Knowledge related to products or services refers to statements Peter et al., (1999) which include:

- Knowledge related to the characteristics or attributes of the product or service for customers and the public;

- Knowledge related to the benefits of the product or service for customers and the community;

- Knowledge related to the added value and satisfaction provided by the product or service for customers and the community.

Positive knowledge will have an impact on increasing the interest of potential users of products and services to use it. Therefore according to Kotler (1994), interest is a person's situation before taking action, which can be used as a basis for predicting someone's behavior or actions. Therefore interest in using mobile banking and internet banking is assumed to be an interest in using bank products and services which are behaviors that emerge as responses to objects that indicate the desire of customers to use them. Knowledge is an external factor for an organization or company so that the information received is positive so that their interest in using the company's products and services also increases. Furthermore, the relationship between promotion, information, knowledge, and interests can be illustrated in Figure 2.1 below: 
Gambar 2.1 Promotional Relations, Knowledge and Interest to Attract Customers

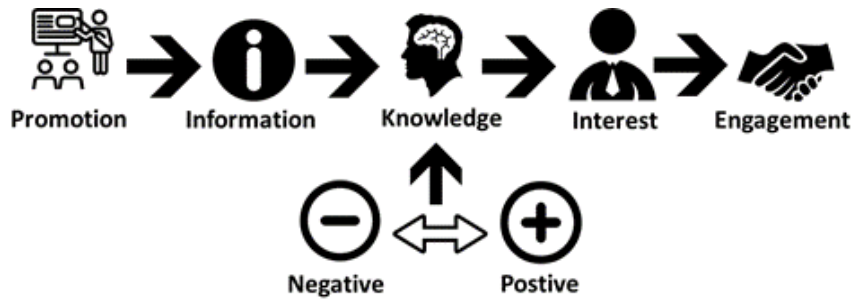

Source: Own

According to Figure 2.1 above, the promotion helps to increase the dissemination of information related to Islamic banking products and services so that the public can receive positive information based on their knowledge which in turn can increase interest in using mobile banking and internet banking.

Also, the classification of the business sector in micro and small businesses aims to determine the characteristics of their businesses based on the business model and business process they run (Nugroho et al., 2018). Furthermore, determining the business sector is very important to develop their businesses and also business opportunities to increase sales turnover. The business sector at the Kemayoran night market target includes Food/Beverage; Accessories; Bags/Shoes/Clothing; Electronics and Home Appliances. The use of mobile banking and internet banking has contributed to the business model of the micro and small business sector. The higher the turnover, the greater the chance for customers or customers of micro and small entrepreneurs to use mobile banking and internet banking in their business transactions.

\section{METHOD}

The method used is qualitative, and the data used are primary in the form of questionnaires which were answered by all the socialization participants who attended a total of 72 micro and small entrepreneurs in the Kemayoran night market community. Condition and location of Kemayoran night market community can be shown in figure 3.1 as follow:

Figure 3.1 Kemayoran Night Market Community
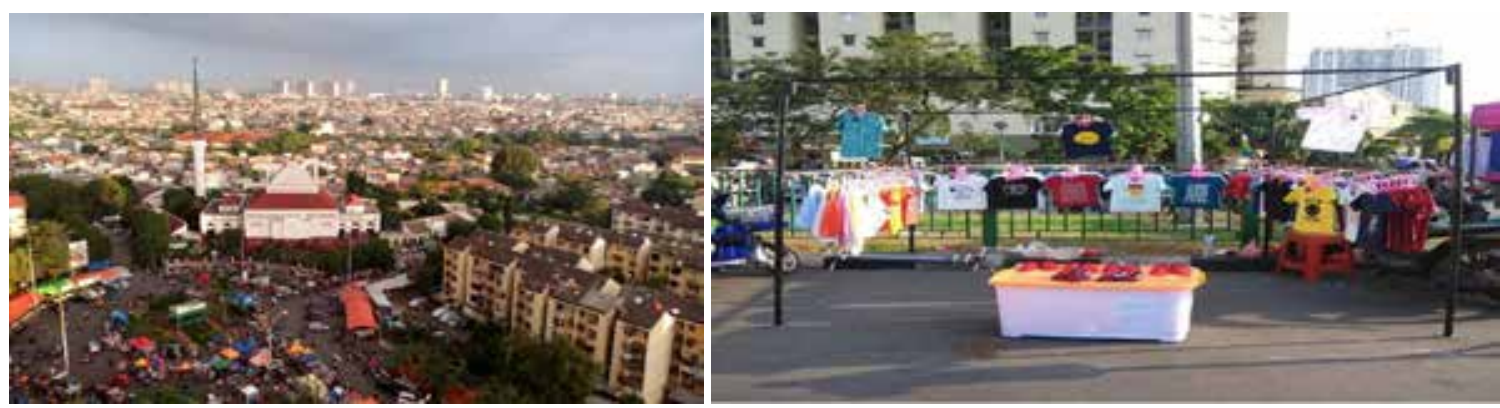

The purpose of the questionnaire is to answer the following research questions:

- How many micro and small women entrepreneurs use mobile and internet banking to support their business?

- What business sectors of micro and small entrepreneurs use the most mobile banking and internet banking in their transactions?

\section{RESULT AND DISCUSSION}

\subsection{Micro and Small Women Entrepreneurs Use Mobile Banking and Internet Banking to Support Their} Business

The socialization activity aims to provide information related to the functions and benefits of using mobile banking and internet banking for micro and small entrepreneurs. Therefore we ask the participants to fill in the questionnaire, and the results of the number of micro and small entrepreneurs comparisons based on gender are shown in table 4.1 as follows: 
Table 4.1 Micro and Small Entrepreneur

\begin{tabular}{|l|r|r|}
\hline Micro and Small Entrepreneur & Amount & Percentage \\
\hline Male & 40 & $56 \%$ \\
\hline Female & 32 & $44 \%$ \\
\hline Total & $\mathbf{7 2}$ & $\mathbf{1 0 0 \%}$ \\
\hline
\end{tabular}

Furthermore, from table 4.1 related to the number of micro and small entrepreneurs based on gender mentioned above, it can be seen the level of education of micro and small entrepreneurs who are classified in Table 4.2 and Graph 4.1 below:

Table 4.2 Micro and Small Entrepreneur Education

\begin{tabular}{|l|r|r|r|r|}
\hline Education & \multicolumn{1}{l|}{ Male } & Female & $\begin{array}{l}\text { Male } \\
\text { Percentage }\end{array}$ & $\begin{array}{l}\text { Female } \\
\text { Percentage }\end{array}$ \\
\hline $\begin{array}{l}\text { Elementary } \\
\text { School }\end{array}$ & 8 & 14 & $20 \%$ & $44 \%$ \\
\hline High School & 20 & 12 & $50 \%$ & $38 \%$ \\
\hline Undergraduate & 10 & 6 & $25 \%$ & $19 \%$ \\
\hline Postgraduate & 2 & 0 & $5 \%$ & $0 \%$ \\
\hline & $\mathbf{4 0}$ & $\mathbf{3 2}$ & $\mathbf{1 0 0 \%}$ & $\mathbf{1 0 0 \%}$ \\
\hline
\end{tabular}

Graph 4.1 Micro and Small Entrepreneur Education

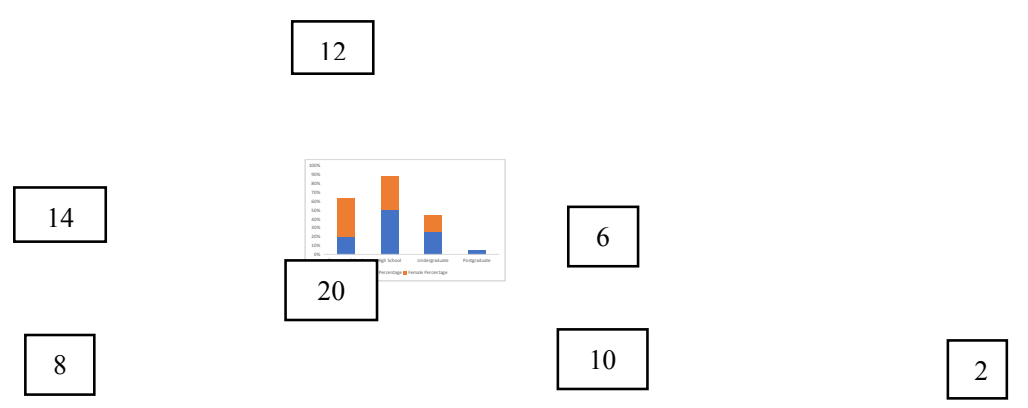

Regarding table 4.2 and graph 4.1 , it is known that overall education from micro and small entrepreneurs with male gender is higher than women entrepreneurs. The portion of micro and small male entrepreneurs with a postgraduate education background is higher in number than female entrepreneurs at $5 \%$ while female entrepreneurs have no postgraduate education background. Whereas the portion of micro and small female entrepreneurs with undergraduate education is also lower than male entrepreneurs, which is $19 \%$ while male entrepreneurs account for $25 \%$. Furthermore, the portion of micro and small female entrepreneurs with a high school education background is also lower when compared to male entrepreneurs, which is $38 \%$ compared to $50 \%$. While the portion of elementary school background of micro and small female entrepreneurs is higher than that of male entrepreneurs, which is $44 \%$ compared to $20 \%$.

Furthermore, the impact of the less knowledge of micro and small female entrepreneurs compared to male entrepreneurs is the low level of female entrepreneurs who use mobile banking and internet banking on their business and financial activities. Comparison of mobile banking and internet banking users is shown in table 4.3 and graph 4.2 below: 
Table 4.3 Micro and Small Entrepreneur Using Mobile Banking and Internet Banking Base on Gender

\begin{tabular}{|l|r|r|l|l|}
\hline Micro and Small Entrepreneur & Male & Female & $\begin{array}{l}\text { Male } \\
\text { Percentage }\end{array}$ & $\begin{array}{l}\text { Female } \\
\text { Percentage }\end{array}$ \\
\hline Use Mobile Banking and Internet Banking & 35 & 10 & $88 \%$ & $31 \%$ \\
\hline $\begin{array}{l}\text { Not Use Mobile Banking and Internet } \\
\text { Banking }\end{array}$ & 5 & 22 & $13 \%$ & $69 \%$ \\
\hline Total & 40 & 32 & $100 \%$ & $100 \%$ \\
\hline
\end{tabular}

Graph 4.2 Micro and Small Entrepreneur Using Mobile Banking and Internet Banking Base on Gender

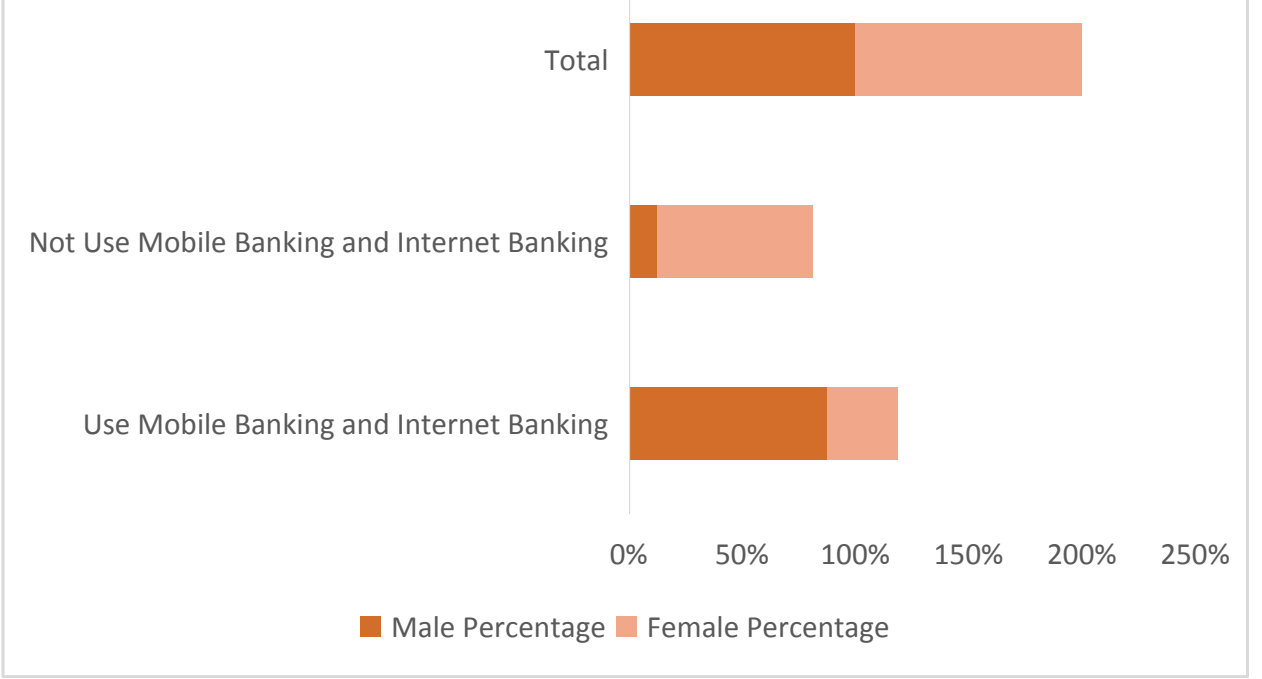

As a result of the low education owned by micro and small female entrepreneurs is the low use of mobile banking and internet banking facilities for these female entrepreneurs compared to male entrepreneurs. Based on table 4.3 and graph 4.2, it is known that the portion of mobile banking and internet banking users of micro dam small businesswomen is still very minimal, which is only $31 \%$. Whereas mobile banking and internet banking entrepreneurs, micro and small male entrepreneurs have reached $88 \%$. Thus the socialization of the functions and benefits of using mobile banking and internet banking was welcomed by micro and small women entrepreneurs located in the Pasar Malam Kemayoran community. Besides, there were also requests from micro and small female entrepreneurs, that it was hoped that financial service providers, in this case, the bank could activate mobile banking and internet banking services directly at their place of business without these female entrepreneurs having to come to the bank's branch. Banks, as financial service providers, must be able to provide mobile banking and internet banking services that are user-friendly and have immediate activation when customers open their savings accounts.

\subsection{The Most Business Sectors of Micro and Small Entrepreneurs which Used Mobile Banking and Internet Banking to Support Their Business}

In addition to increasing fee-based income from banks, banks must know which business sectors are dependent or need mobile banking and internet banking services to market these services. This business sector is determined based on business models and business processes of each business sector that has similarities (Nugroho, Hidayah, \& Badawi, 2018). The development of e-commerce today many business sectors in the field of clothing and food and beverages have used online services in sales. The impact of the development of ecommerce has caused these micro, and small entrepreneurs to no longer rely on physical sales, but they also sell their products and services through online facilities. (Nugroho \& Tamala, 2018). Based on the survey that we conducted at the time of socialization, there is information on the use of mobile banking and internet banking following table 4.4 as follows: 
Table 4.4 The Micro and Small Entrepreneur Using Mobile Banking and Internet Banking Base on Business Sector

\begin{tabular}{|c|c|c|c|c|}
\hline Business Sector & Responden & $\begin{array}{l}\text { Use Mobile Banking and } \\
\text { Internet Banking }\end{array}$ & $\begin{array}{l}\text { Not Use Mobile Banking } \\
\text { and Internet Banking }\end{array}$ & $\begin{array}{l}\text { Use Mobile Banking and Internet } \\
\text { Banking base on Business Sector }\end{array}$ \\
\hline Food and Beverages & 15 & 12 & 3 & $27 \%$ \\
\hline Accessories & 10 & 1 & 9 & $2 \%$ \\
\hline Bags, Shoes and Clothing & 37 & 31 & 6 & $69 \%$ \\
\hline Electronic & 5 & 1 & 4 & $2 \%$ \\
\hline Household appliances & 5 & 0 & 5 & $0 \%$ \\
\hline Total & 72 & 45 & 27 & $100 \%$ \\
\hline
\end{tabular}

According to table 4.4, it is known that the business sectors that use the most mobile banking and internet banking services are the business bags, shoes, and clothing sector which are then followed by the food and beverage business sector. Following the results of the survey, the banking industry can set their target market to increase fee-based income through the intensive promotion of the business sector of bags, shoes, and clothing as well as food and beverage to use mobile banking and internet banking services.

Also, the purpose of the socialization of the use of mobile banking and internet banking is to make it easier for micro and small entrepreneurs in financial transactions to increase sales of their businesses. This socialization activity is an action that supports the implementation of the SDG's program in terms of alleviating poverty and empowering women and reducing the use of paper due to using mobile banking and internet banking applications.

\section{CONCLUSION}

Literacy on mobile banking and internet banking services for micro and small women entrepreneurs still needs to be improved, one of which is through service to the community through socialization that we are currently doing as lecturers at Mercu Buana University, Jakarta. In addition to the effectiveness of its sales, micro and small entrepreneurs should now use e-commerce facilities in order to expand their sales network. Business sectors that use the most mobile banking and internet banking services, namely bags, shoes and clothing and also food and beverage, tend to market their products through e-commerce because of the need for their business transactions.

\section{REFERENCES}

Adiarsi, G. R., Stellarosa, Y., \& Silaban, M. W. (2015). Literasi Media Internet di Kalangan Mahasiswa. Humaniora, 6(4), 470-482.

Ainiyah, N., Ibrahimy, U., \& Situbondo, S. (2018). Remaja Millenial dan Media Sosial: Media Sosial sebagai Media Informasi Pendidikan bagi Remaja Millenial. Jurnal Pendidikan Islam Indonesia, 2(2), 221-236.

Chaudhry, I. S., \& Nosheen, F. (2009). The determinants of women empowerment in Southern Punjab (Pakistan): An empirical analysis. European Journal of Social Sciences, 10(2), 216-229.

Endy Purwanto. (2019). 2018: Pengguna Smartphone Indonesia Tembus 103 Juta Orang. Retrieved August 14, 2019, from https:/www.ayooberita.com/berita-----2018-pengguna-smartphone-indonesia-tembus-103-jutaorang

Gholipour, A., Rahimian, A., Mirzamani, A., \& Zehtabi, M. (2010). IMPACT model of women's empowerment. International Business Research, 3(1), 57-65.

Hidayah, N., Nugroho, L., \& Badawi, A. (2018). Socialization and Training for Productive Household Budget for Household Mother In Meruya Selatan Village. ICCD, 1(1), 523-527.

Jaidan, J. (2010). Upaya Pengembangan Usaha Kecil Menengah (UKM) Dengan Memanfaatkan E-Commerce. Jurnal Sistem Informasi, 2(1), 159-168. https://doi.org/ISSN Online : 2355-4614

Jati, W. R. (2015). Bonus Demografi Sebagai Mesin Pertumbuhan Ekonomi: Populasi, 26(Bonus Demografi Sebagai Mesin Pertumbuhan Ekonomi), 1-19.

KEMENKEU. (2019). Kelas Menengah Penggerak Ekonomi Indonesia. Retrieved August 14, 2019, from https://www.kemenkeu.go.id/publikasi/berita/kelas-menengah-penggerak-ekonomi-indonesia/

Khan, T. M., \& Maan, A. A. (2008). Socio-Cultural Milieu of Women's Empowerment in District Faisalabad. 
Pakistan Journal of Agriculture Sciences, 45(3), 78-90.

Kotler, P. (1994). Reconceptualizing marketing: An interview with Philip Kotler. European Management Journal, 12(4), 353-361. https://doi.org/10.1016/0263-2373(94)90021-3

Kristiyanti, M. (2012). Peran Strategis Usaha Kecil Menengah (UKM) Dalam Pembangunan Nasional. Majalah Ilmiah INFORMATiKA, Vol 3(1), 63-89.

Linawati, E., \& Restuti, M. M. D. (2015). Pengetahuan akuntansi pelaku usaha mikro, kecil dan menengah (UMKM) atas penggunaan Informasi Akuntansi. In 2nd Conference in Business, Accounting, and Management (Vol. 2, pp. 145-149).

Mulyana, M., Mulyana, A. R., \& Dewi, A. K. (2018). Perancangan Kampanye untuk Menumbuhkan Kesadaran Generasi Millenial terhadap Dampak Nomophobia. Jurnal Rekamakna, 1(1), 1-10.

Munizu, M. (1990). Pengaruh Faktor-Faktor Eksternal dan Internal Terhadap Kinerja Usaha Mikro dan Kecil (UMK) di Sulawesi Selatan. Jurnal Manajemen Dan Kewirausahaan, 12(1), 33-41.

Najjar, S. (2011). Women's empowerment and peace-building under occupation? Palestine-Israel Journal of Politics, Economics and Culture, 17(3-4), 59-66.

Nisak, A., Saryadi, \& Suryoko, S. (2013). Pengaruh Kelompok Acuan dan Pengetahuan tentang Perbankan Syariah terhadap Minat Menabung di Perbankan Syariah Semarang. Jurnal Ilmu Administrasi Bisnis , $1(1), 44-50$.

Nugroho, L., \& Chowdhury, S. L. K. (2015). Mobile Banking for Empowerment Muslim Women Entrepreneur: Evidence from Asia (Indonesia and Bangladesh). Tazkia Islamic Finance \& Business Review, 9(1), 83100 .

Nugroho, L., Hidayah, N., \& Badawi, A. (2018). The Islamic Banking, Asset Quality: "Does Financing Segmentation Matters" (Indonesia Evidence). Mediterranean Journal of Social Sciences, 9(5), 221-235. https://doi.org/10.2478/mjss-2018-0154

Nugroho, L., \& Tamala, D. (2018). Persepsi Pengusaha UMKM Terhadap Peran Bank Syariah. SIKAP, 3(1), 4962 .

Nugroho, L., Utami, W., Sanusi, Z. M., \& Setiyawati, H. (2018). Corporate Culture and Financial Risk Management in Islamic Social Enterprises (Indonesia Evidence). International Journal of Commerce and Finance, 4(January), 12-24.

Peter, J. ., Olson, J. ., \& Grunert, K. . (1999). Consumer Behaviour and Marketing Strategy (Vol. 3). London: McGraw-Hill.

Prastowo, N. L. (2015). The Challenges of Islamic Microfinance (Indonesia Evidence). European Journal of Islamic Finance, O(1), 1-7. https://doi.org/10.13135/2421-2172/793

Pressman, S. (2015). The Decline of the Middle Class: An International Perspective. Journal of Economic Issues, 41(1), 181-200.

Rahman, M., Karmaker, U. K., \& Mia, A. R. (1970). Determinants of Women Empowerment at Domestic and Non-domestic Issues: Evidence from Chapai Nawabganj District in Bangladesh. Dhaulagiri Journal of Sociology and Anthropology, 3, 143-162. https://doi.org/10.3126/dsaj.v3i0.2784

Rizky Alika. (2019). 85 Juta Penduduk Kelas Menengah di 2020, Peluang Bagi Industri Kreatif | Katadata News. Retrieved August 14, 2019, from https://katadata.co.id/berita/2019/01/23/85-juta-penduduk-kelasmenengah-di-2020-peluang-bagi-industri-kreatif

Sheikh, Q. A., Meraj, M., \& Mahapara Sadaqat. (2016). Gender equality and socio-economic development through women' s empowerment in Pakistan. Ritsumeikan Journal of Asia Pacific Studies, 34, 150-160.

Sridharan, E. (2004). The Growth and Sectoral Composition of India's Middle Class: Its Impact on the Politics of Economic Liberalization. India Review, 3(4), 405-428. https://doi.org/10.1080/14736480490895769

Sumantri, B., Fariyanti, A., \& Winandi, R. (2013). Faktor-Faktor yang Berpengaruh terhadap Kinerja Usaha Wirausaha Wanita: Suatu Studi pada Industri Pangan Rumahan di Bogor. Jurnal Manajemen Teknologi, 12(3), 252-277.

Tijani, S. A., \& Yani, I. (2007). Assesment of Current Status of Women Farmers in Japan Using Empowerment Indicators. Journal of Applied Sciences, 7(20), 3006-3014.

Wallentin, F. (2008). Economic or Non-Economic Factors - What Empowers Women ? Working Paper Series. 
Yazdi, M. (2012). E-Learning sebagai Media Pembelajaran Interaktif Berbasis Teknologi Informasi. Jurnal Ilmiah Foristek, 2(1), 143-152.

Yudha Pratomo, K. C. (2019). APJII: Jumlah Pengguna Internet di Indonesia Tembus 171 Juta Jiwa. Retrieved August 14, 2019, from https://tekno.kompas.com/read/2019/05/16/03260037/apjii-jumlah-penggunainternet-di-indonesia-tembus-171-juta-jiwa 